\title{
IDENTIFICATION OF SYSTEM MODELS FROM POTENTIAL-STREAM EQUATIONS ON THE BASIS OF DEEP LEARNING ON EXPERIMENTAL DATA
}

\author{
I.E. STAROSTIN ${ }^{1}$, S.P. KHALYUTIN ${ }^{1}$ \\ ${ }^{1}$ Moscow State Technical University of Civil Aviation, Moscow, Russia
}

The functioning of various systems (in particular technical objects, living cells, the atmosphere and the ocean, etc.) is determined by the course of physical and physico-chemical processes in them. In order to model physicochemical processes in the general case, the authors previously developed a potential-flow method based on an experimental study (on the results of system tests) of the properties of substances and processes. In the general case, from these experimental data, many possible values of these properties are obtained. Knowing these properties of substances and processes, the initial state of the system, external influences on it (or the set of possible values of these quantities), we can analyze the dynamics of physicochemical processes in this system, and from it the dynamics of the characteristics of this system that have practical meaning. Thus, from the system of equations of this method, a relationship is obtained between the unobservable characteristics of these systems with the observed characteristics of the systems and laboratory systems under consideration (in which the properties of substances and processes in the system under study are experimentally studied). As the potential flow equations describing the physicochemical processes are generally quite complicated for analytical transformations, the aforementioned relationship must be obtained by numerical methods. The present work is devoted to the use of deep learning as a universal approximator for obtaining the described connection between the characteristics of arbitrary systems. These models are trained on the dynamics of the characteristics of the systems under consideration, obtained from potential-flow equations of physicochemical processes in them for different values of the parameters that determine the properties of substances and processes in these systems, their initial states, and external influences.

Key words: physical and chemical processes, mathematical modeling, potential-streaming method, deep learning.

\section{INTRODUCTION}

Potential -stream method is the consistent approach to the physico-chemical processes modelling. It was developed in previous years in the general case in the context of modern non-equilibrium thermodynamics $[1,2]$. The method coopts particular cases of physico-chemical process model [3]. A flow chart outlining the approach is shown in Figure $1[3,4]$.

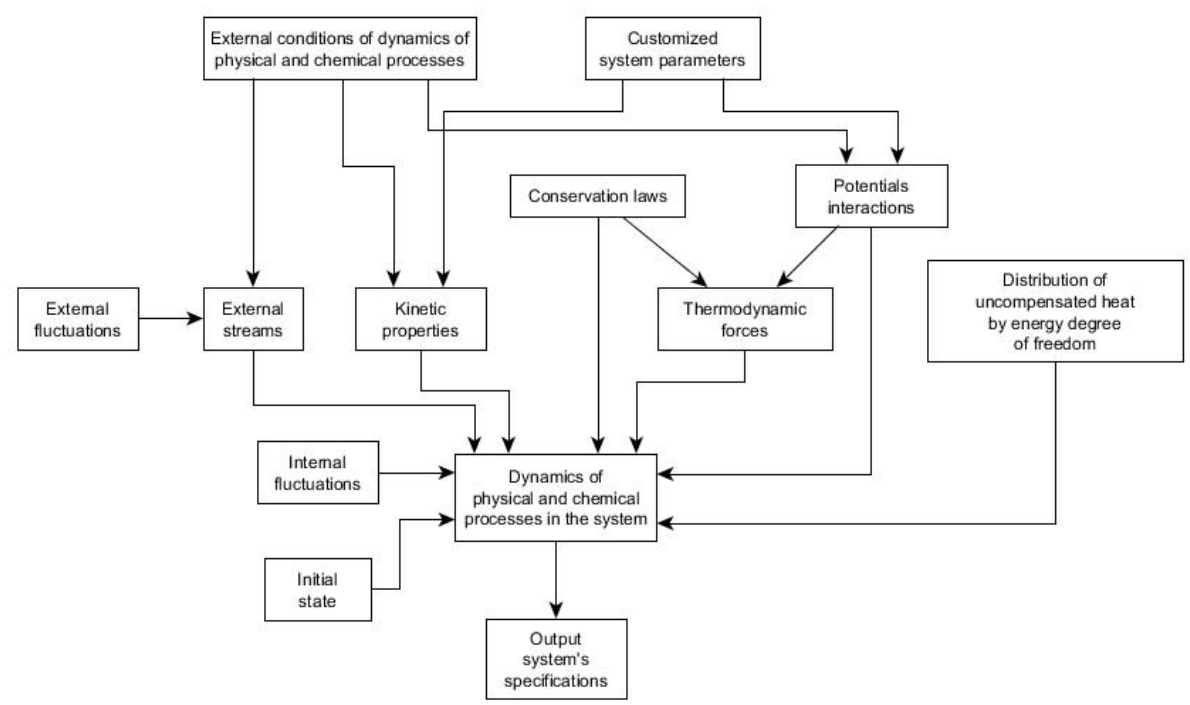

Fig. 1. Potential-streaming method 
The purpose of the present article is development of unobservable and observable data of the certain system and laboratory systems connection formula by reference to potential-stream equations of physico-chemical processes in these systems. Basically, the observed system data at the following timepoints might be its unobservable data (providing that we cannot wait for the future coming in the aim of, the data measurement in it, for instance, in forecasting problems [5, 6]; nevertheless thereafter these data will be called observed) and basically non-measurable data (basically unobservable, thereafter unobservable; is seen in diagnostic tasks $[5,6])$.

\section{DIAGNOSTIC AND PROGNOSTIC SYSTEM MODELS}

Observable data amounts of the certain $\operatorname{system}_{\mathbf{z}}(t)$ at the following timepoints connection with these data $\mathbf{z}(t)$ at the present and the previous timepoints and with the acquainted input actions on this object $\mathbf{s}(t)[5]$ :

$$
\mathbf{v}_{\mathbf{z}}(t)=\mathbf{f}\left(\mathbf{x}_{\mathbf{z}}(t), \mathbf{x}_{\mathbf{s}}(t), \mathbf{q}\right)+\mathbf{e}_{\mathbf{z}}(t)
$$

where $\mathbf{v}_{\mathbf{z}}(t)$ are observable $\mathbf{z}(t)$ data highest derivatives; $\mathbf{z}(t) ; \mathbf{x}_{\mathbf{z}}(t)$ are observable data and their lowest derivatives; $\mathbf{x}_{\mathbf{s}}(t)$ are the acquainted input actions $\mathbf{s}(t)$ and their derivatives; $\mathbf{q}$ are the data derived from the considered system and laboratory systems test results. Physical and chemical processes in the considered system are researched experimentally in laboratory systems; $\mathbf{e}_{\mathbf{z}}(t)$ are the noise components (thereafter will be called prognostic mathematic model of the considered system [5]).

Unobservable data amounts of the considered technical object $\mathbf{y}(t)$ at the present timepoints with the data amounts at the previous timepoints and observable data of the system $\mathbf{z}(t)$ at the present and previous timepoints (and in the general case with the acquainted input actions on it $\mathbf{s}(t)[5])$ :

$$
\mathbf{v}_{\mathbf{y}}(t)=\mathbf{g}\left(\mathbf{x}_{\mathbf{y}}(t), \mathbf{x}_{\mathbf{z}}(t), \mathbf{x}_{\mathbf{s}}(t), \mathbf{q}\right)+\mathbf{e}_{\mathbf{y}}(t), \quad \mathbf{x}_{\mathbf{y}}\left(t_{0}\right)=\tilde{\mathbf{g}}\left(\mathbf{x}_{\mathbf{z}}\left(t_{0}\right), \mathbf{x}_{\mathbf{s}}\left(t_{0}\right), \mathbf{q}\right)+\mathbf{e}_{\tilde{\mathbf{y}}}
$$

where $\boldsymbol{v}_{\boldsymbol{y}}(t)$ are the unobservable data $\boldsymbol{y}(t)$ of the considered system highest derivatives; $\boldsymbol{x}_{\boldsymbol{y}}(t)$ are the unobservable outcoming data $\boldsymbol{y}(t)$ and their lowest derivatives; $\boldsymbol{e}_{\boldsymbol{y}}(t)$ are the noise components (thereafter will be called the diagnostic model [5]).

\section{WAYS OF DERIVING THE DIAGNOSTIC AND PROGNOSTIC MODELS FROM THE EQUATIONS OF PHYSICO-CHEMICAL PROCESSES}

As noted above, it is necessary to suppress motional states from the potential - flow equations system in the aim of diagnostic and prognostic models derivation (1) and (2). Motional states label the system state at every timepoint apart from its pre-history [1-4], coefficients which obtain the features of substances and processes [1-5] and indeterminate input actions [5].

The suppression may be realized in two ways [6]:

- analytical approach (by potential -stream equations of physico-chemical processes analytic transformation)

- numerical approach (by using Monte-Carlo methods: statistically distributed potentialstream equations value assignment, reckoning of the relevant system characteristics from the coupled equations and generating the connection between these data based on their reckoned multitude). 
In the general case analytic transitions mentioned above are quite complicated [6] due to the compilation of potential-driven coupled equations of physical and chemical processes $[1,3,4]$ (even involving simplification, which only cumulates the complexity [6]). Thus, it is necessary to generate the connection between the relevant technical object common sense data numerically, by using MonteCarlo methods [6].

There are either classical machine learning methods [7, 8] or deep learning approaches $[8,10-22]$ which might be used in the aim of diagnostic and prognostic model approximation (1) and (2) by using the numerical-analytic methods. The classical methods are heading from the recognition theory methods [9] (seen from [7-9]).

\section{CHOOSING MACHINE LEARNING METHODS WITH THE AIM OF MODEL GENERATING FROM THE DOUBLED PROCESS EQUATIONS}

Traditional machine learning methods $[7,8]$ accept preprocessed data at the entry $[7,8]$, as the recognition methods do [9]. That means that it is necessary to normalize the data multitudes generated by Monte-Carlo methods to the state which traditional machine learning algorithms work with $[7,8]$ in purpose of generating the correspondences between common sense data characteristics mentioned above. The posterior data on connection between these characteristics is necessary in the aim of normalizing these data to this state. Nevertheless, in the general case (due to the complexity of physico-chemical process behavior [1-4]) it is also necessary to simplify these coupled equations in the aim of the posterior data receiving, which tangibly enlarges the analysis complexity.

Deep learning methods (particularly, based on neural networks), unlike the traditional ones, do not require the preparatory data handling (in that case there are system data amounts, generated by means of the approach mentioned above, involving Monte-Carlo methods). These deep machine learning methods extract all the necessary features for modelling by themselves $[8,10-22]$.

Nevertheless, the large training data amount is required for using the deep learning methods $[8,10-14]$, but in this case the required amount of training data is derived by numerical potentialstream coupled equations integrating for different statistically assigned amounts (according to MonteCarlo methods), which obtain the process dynamics in the system $[5,6,11,12,14]$. Consequently, deep machine learning methods are the most appropriate ones for solving the problems of diagnostic and prognostic models generation (1) and (2) mentioned above.

It should also be noted that the models (1) and (2) which are realized particularly by neural networks are trained by not experimental data, but by doubled equations of physico-chemical processes in the system. The model coopts physical and chemical process features of the system due to this. The model accepts experimental data at the entry after the training by doubled potential-stream equations of physical and chemical processes $[6,11,12,14]$.

Symbolic regression methods are also universal approximators [23-26]. It is seen from [23-26] that these models are of neural network configuration. Symbolic regression models generation and training is analogous to the one of neural networks [16-26]. Moreover, both symbolic regression and neural network approximation is based on the approximation generalized theorem $[15,16,18,20]$. Using of neural networks structure automatic design methods along with genetic algorithms, also robotizes neural network (approximation model) structure establishment [19-22], by analogy with symbolic regression methods [23-26].

It should also be noted that it is enough to take one nonlinear element and to build approximation models $[12,15,16,18,20]$ involving it in the aim of solving the approximation problems (along with the problems covered in the present article) by using neural networks or symbolic regression methods. Nevertheless, in this case approximation is becoming tedious [20], consequently, it is neces- 
sary to use different nonlinear functional relations in the aim of making the model as simple as possible. That is what symbolic regression and neural network methods coopt along with the neural network automatic design [20].

Moreover, involving methods of representation and rendering the information from the neural networks [17, 27] along with the block-oriented synthesis and neural network training [12, 17] makes using of the neural networks intuitive (along with involving the symbolic regression methods).

The analytic simplification of the potential - data driven equations mentioned above is also reduced to the symbolic regression and, consequently, to the neural networks, analogical to it.

Consequently, choosing the method of diagnostic and prognostic modelling (1) and (2) from the potential-data driven physical and chemical equations, using either the neural networks, involving the neural network automatic design and representation and rendering the information or the symbolic regression, is matched. Thus, thereafter the matter will concern the neural networks representing these models (1) and (2).

\section{THE DESIGN OF NEURAL NETWORKS REPRESENTING THE DIAGNOSTIC AND PROGNOSTIC SYSTEM MODELS}

The main neural network function in the context of the current task is the data approximation (that was mentioned in the works $[10-13,15,16,18,20]$ ). The data is received from the potentialstream equations of physico-chemical processes. The neural networks offer the multilayer perceptron, the feedforward neural networks.

There is the algorithm of making such an approximation multilayer perceptron, as simple as possible (at the cost of choosing the approximation functional relations) [20]. It is based on the network building-up, training and reduction (extra neuron and synaptic links removal [20]) combination. It is seen from [20] that simplification of neural network structure is analogous to the one for the analytical formulas, along with the neural network building-up which is analogous to the one for the clarification of the analytic formulas (by the methods, mentioned in the works [23-26], seen from [20]).

It is seen in the Figure 1 that the dynamics of the certain technical object are obtained by $[5,6]$ :

- the coefficients of the functional substance features development (which do not change from one given model system item to another one, do not depend on its mode of operation, are obtained by laboratory system set tests);

- the individual system characteristics (which do not depend on the given model system mode of operation but change from one its item to another one, are obtained from its control mode of operation);

- the reference state, system external actions (which depend on the given model system mode of operation and change from one its item to another one).

Thus, in the first place it is necessary to suppress the dynamic state coordinates and indeterminate certain system external actions [6] from the doubled potential-data driven equations; the diagnostic and prognostic models (1) and (2) will be generated up to the individual characteristics $\boldsymbol{p}$ and the coefficients of functional substance and process features $\boldsymbol{c}$ [6] development (formal diagnostic and prognostic models [6]):

$$
\begin{gathered}
\mathbf{v}_{\mathbf{z}}(t)=\overline{\mathbf{f}}\left(\mathbf{x}_{\mathbf{z}}(t), \mathbf{x}_{\mathbf{s}}(t), \mathbf{p}, \mathbf{c}\right)+\mathbf{e}_{\mathbf{z}}(t), \\
\mathbf{v}_{\mathbf{y}}(t)=\overline{\mathbf{g}}\left(\mathbf{x}_{\mathbf{y}}(t), \mathbf{x}_{\mathbf{z}}(t), \mathbf{x}_{\mathbf{s}}(t), \mathbf{p}, \mathbf{c}\right)+\mathbf{e}_{\mathbf{y}}(t), \quad \mathbf{x}_{\mathbf{y}}\left(t_{0}\right)=\overline{\tilde{\mathbf{g}}}\left(\mathbf{x}_{\mathbf{z}}\left(t_{0}\right), \mathbf{x}_{\mathbf{s}}\left(t_{0}\right), \mathbf{p}, \mathbf{c}\right)+\mathbf{e}_{\tilde{\mathbf{y}}},
\end{gathered}
$$


In the general case the equations might be noted down this way:

$$
\begin{gathered}
\mathbf{v}_{\mathbf{z}}(t)=\overline{\mathbf{f}}\left(\mathbf{x}_{\mathbf{z}}(t), \mathbf{x}_{\mathbf{s}}(t), \mathbf{p}^{*}, \mathbf{c}^{*}\right)+\mathbf{e}_{\mathbf{z}}(t) \\
\mathbf{v}_{\mathbf{y}}(t)=\overline{\mathbf{g}}\left(\mathbf{x}_{\mathbf{y}}(t), \mathbf{x}_{\mathbf{z}}(t), \mathbf{x}_{\mathbf{s}}(t), \mathbf{p}^{*}, \mathbf{c}^{*}\right)+\mathbf{e}_{\mathbf{y}}(t), \quad \mathbf{x}_{\mathbf{y}}\left(t_{0}\right)=\overline{\tilde{\mathbf{g}}}\left(\mathbf{x}_{\mathbf{z}}\left(t_{0}\right), \mathbf{x}_{\mathbf{s}}\left(t_{0}\right), \mathbf{p}^{*}, \mathbf{c}^{*}\right)+\mathbf{e}_{\tilde{\mathbf{y}}},
\end{gathered}
$$

where

$$
p^{*}=b_{p}(p, c), c^{*}=b_{c}(c)
$$

at

$$
\operatorname{dim}\left(\boldsymbol{p}^{*}\right) \leq \operatorname{dim}(\boldsymbol{p}), \operatorname{dim}\left(\boldsymbol{c}^{*}\right) \leq \operatorname{dim}(\boldsymbol{c})
$$

Thereafter the coefficients $\mathbf{c}^{*}$ are "the general coefficients of the certain system model", and the coefficients $\boldsymbol{p}^{*}$ are "the presented individual characteristics of the technical object". In the fulfillment of the condition (8) general case it is appropriate to obtain the $\mathbf{c}^{*}$ and $\mathbf{p}^{*}$ characteristics, but not the $\boldsymbol{c}$ and $\boldsymbol{p}$ (from the results of laboratory system set tests and control tests).

In the aim of formal prognostic and diagnostic models (3) and (4) generation according to the given methods we shall assign the multitude of the amounts at the entry (in the Figure 2a), according to the Monte-Carlo methods, and train the multilayer perceptron mentioned above, which represents the formal diagnostic and prognostic models (3) and (4) of the object (Figure 2). Thereafter, involving the approach mentioned above we shall receive extra (test) data, then check the trained multilayer perceptron (Figure 2) basing on them, and update the perceptron whether it is necessary.

Then we shall simplify the multilayer perceptron using the approaches mentioned above (and in [20]). It is appropriate to represent the perceptron in the block configuration (Figure 2b) after such a simplification. Such a simplified perceptron represents formal diagnostic and prognostic models (5) - (7), from (3) and (4).

In order to generate the model (by the methods $[11,14]$ ), which links the results of laboratory system set tests with the $\boldsymbol{c}$ coefficients of the substance and process functional development (or with the general $\boldsymbol{c}^{*}$ coefficients of the certain system model in case of the condition (8) fulfillment) the amounts at the entry are statistically assigned according to the Monte-Carlo methods (in the Figure 3); the model of the multilayer perceptron mentioned above is trained basing on this multitude (Figure3). The compressibility of these dynamics is in operation during the training (we shall get the appropriate coefficients which will be the results of the laboratory system set tests; rated). There after we shall generate the test data for testing the multilayer perceptron which represents the connection between the $\boldsymbol{c}$ coefficients (or the general $\boldsymbol{c}^{*}$ coefficients in case of the condition (8) fulfillment) and the appropriate results of the laboratory system set tests, then test the perceptron (Figure 3 ) and update it whether it is necessary.

In the aim of obtaining the individual $\boldsymbol{p}$ characteristics (or the presented individual characteristics $\boldsymbol{p}^{*}$ of the technical object in case of the condition (8) fulfillment) using the methods [11,14] it is necessary to train the multilayer perceptron, which represents the connection between the $\boldsymbol{p}$ characteristics (or the presented individual $\boldsymbol{p}^{*}$ characteristics of the technical object in case of the condition (8) fulfillment), the $\boldsymbol{c}$ coefficients (or the $\boldsymbol{c}^{*}$ coefficients in case of condition (8) fulfillment) and the results of the technical object tests (Figure 4), analogically to the mentioned above. Then the data are received using the given approach, the perceptron is being tested (Figure 4) basing on them and is being updated whether it is necessary. 
a)
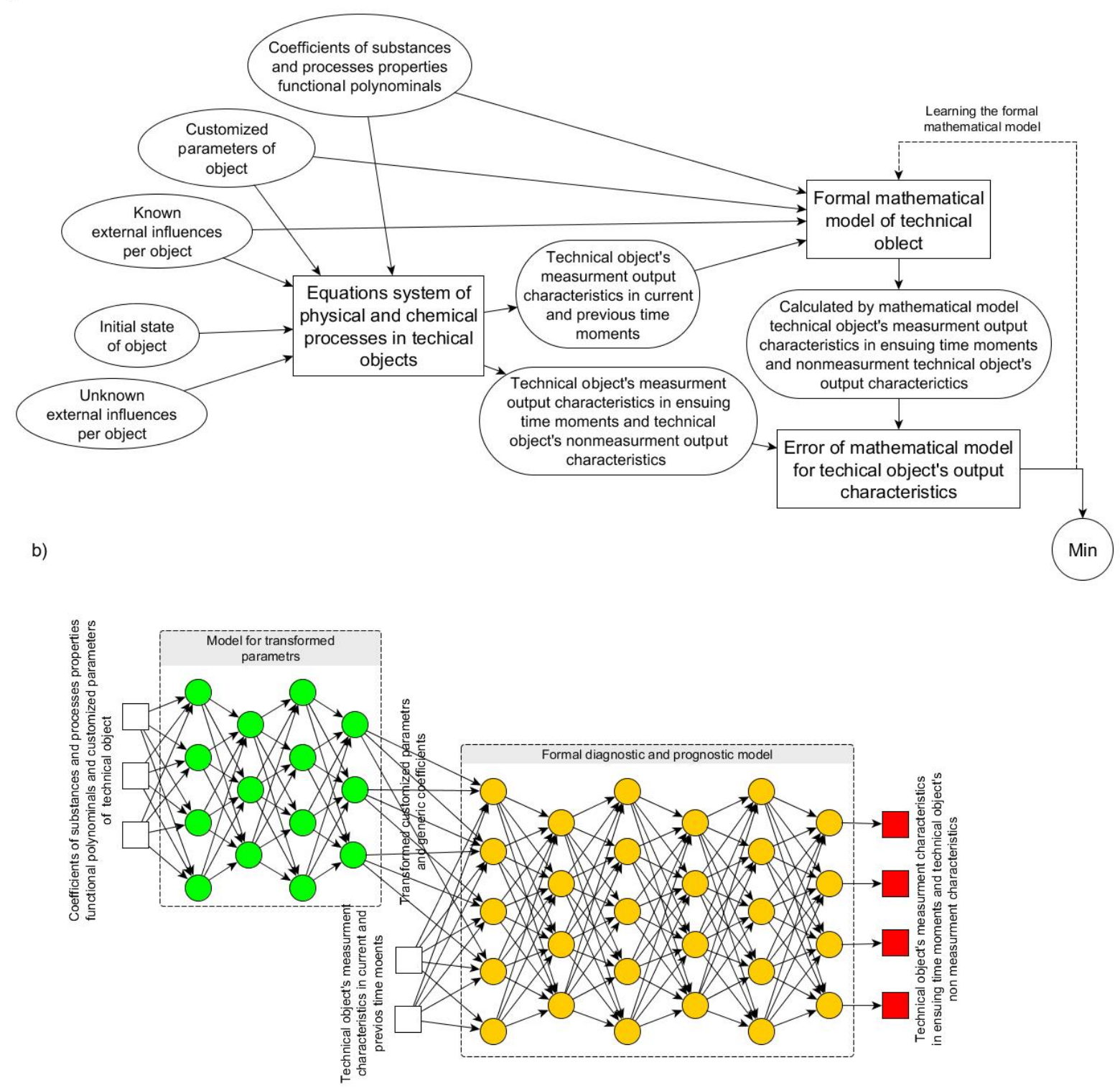

Fig. 2. Formal diagnostic and prognostic model: a) construction of a formal model, b) structure of a formal mathematical model (diagnostic and prognostic model)

Thus, the mathematical model of the considered technical object (up to this object and laboratory system test activity) generated by the described approach from the physico-chemical process equations in this object and in the laboratory systems has three components:

- formal diagnostic and prognostic models (3) and (4) (or (5) - (7) in case of condition (8) fulfillment);

- model for linking the $\boldsymbol{c}$ coefficients (or the $\boldsymbol{c}^{*}$ characteristics coefficients in case of the condition 8 fulfillment) with the laboratory system test activity results;

- model for linking the individual $\boldsymbol{p}$ characteristics (or the presented individual $\boldsymbol{p}^{*}$ characteristics in case of condition (8) fulfillment with this object test activity results).

Such generated mathematical models ought to be checked basing on the results of the extra technical object tests. 


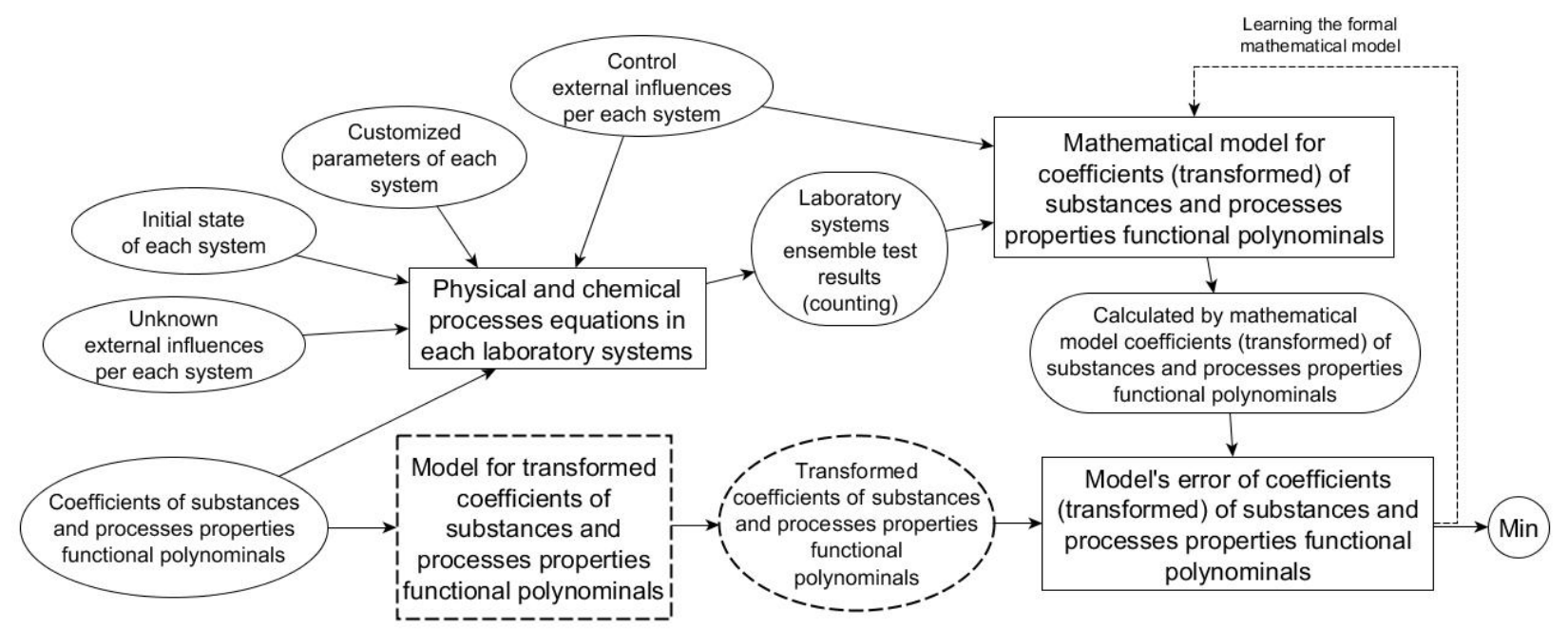

Fig. 3. The construction of a mathematical model for the coefficients of (reduced) functional decompositions of the properties of substances and processes. If condition (8) is not fulfilled, the given coefficients are equal to these coefficients themselves

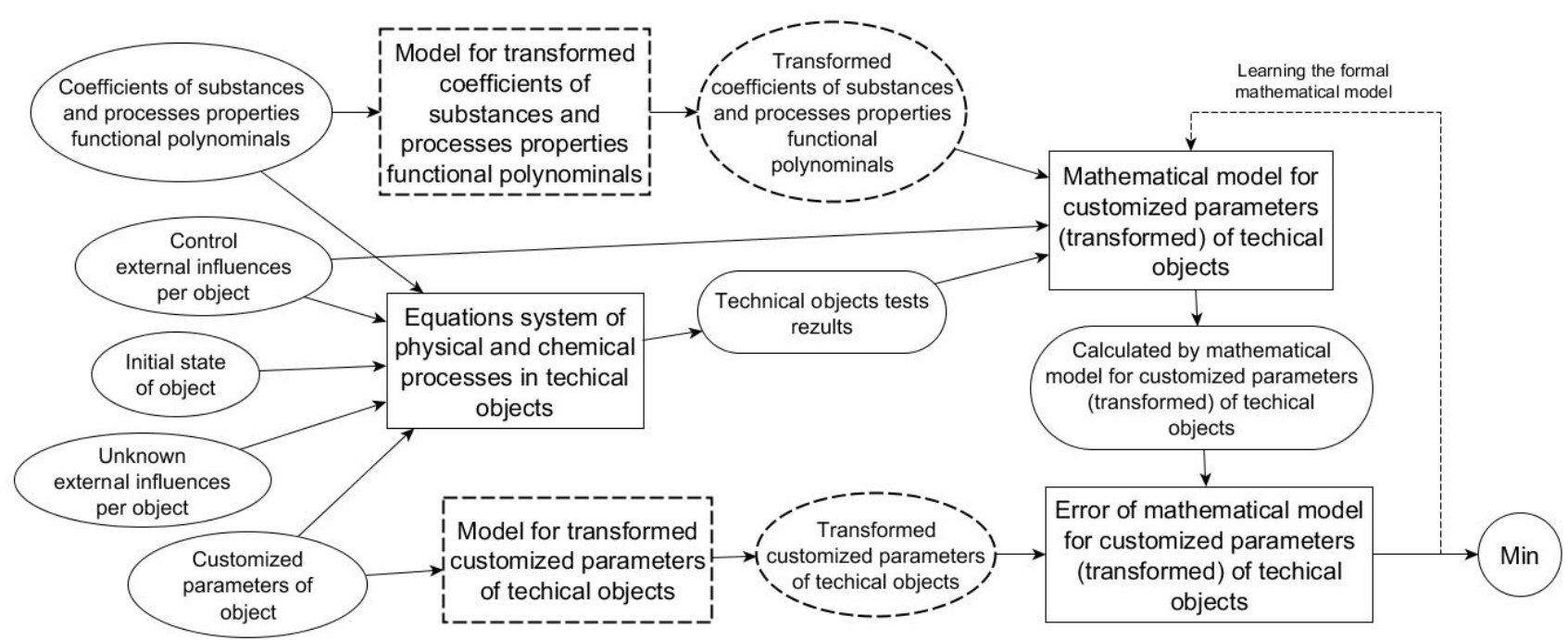

Fig. 4. Construction of a mathematical model for individual parameters (reduced). In case of failure of condition (8), the given coefficients and the given individual parameters are equal to these coefficients and individual parameters, respectively

Such mathematical models ought to be generated in the same way for the laboratory system sets in the aim of checking the models basing on the laboratory system set tests results and, consequently, for checking the reasonability of the reference information.

\section{CONCLUSION}

The present work covers numerical-analytic methods of generating diagnostic and prognostic models of the certain system from the coupled potential-stream equations of the physical and chemical processes in the objects up to the object and laboratory system test results, based on the deep learning methods. Moreover, it is seen that the given numerical - analytic methods might be suitable for build- 
ing the model of any coupled equations of physical and chemical processes (not only the potentialstream equations). The neural network model for the angular velocity of the electric motor is synthesized basing on the approach described in the article [14].

Involving the block representation of the physical methods (along with the potential- stream approach [4]) and robotizing the mathematic model generating approaches from the coupled equations of physico-chemical processes, described in the present work, we shall receive the robotized system of generating the certain system mathematical model by analyzing the physical and chemical processes in the system and the test results.

\section{REFERENCES}

1. Etkin, V.A. (2008). Energodinamika: sintez teoriy perenosa i preobrazovaniya energii [Energy dynamics: theories' synthesis of energy transfer and transformation]. St. Petersburg: Science, 409 p.

2. Jou, D., Casas-Vázquez, J. and Lebon, G. (2006). Extended irreversible thermodynamics. New York, USA: Springer, 528 p.

3. Starostin, I.E. and Bykov, V.I. (2017). Kinetic theorem of modern non-equilibrim thermodynamic. Raleigh, Noth Caroline, USA: Open Science Publishing, 229 p. (in Russian)

4. Starostin, I.E. and Stepankin, A.G. (2019). Programmnaya realizatsiya metodov sovremennoy neravnovesnoy termodinamiki. I sistema simulyatsii fiziko-khimicheskikh protsessov SimulationNonEqProcSS v.0.1.0 [Software implementation of modern nonequilibrium thermodynamic methods. Also, the simulation system of physical and chemical processes. SimulationNonEqProcSS v.0.1.0]. Lambert academic publishing RU, 132 p. (in Russian)

5. Starostin, I.E. and Khalutin, S.P. (2019). Obtaining robotic objects model from the equations of the potential-flow method. $20^{\text {th }}$ international conference on micro/nanotechnologies and electron devices EDM, Novosibirsk, June 29 - July 3 2019, pp. 678-684.

6. Starostin, I.E. (2019). Methodology for obtaining a mathematical model of an operated object from potential-flow equations of physical and chemical processes. Nauchnyye gorizonty, no. 10 (26), pp. 197-206. (in Russian)

7. Flach, P. (2015). Machine Learning. The Art and Science of Algorithms that Make Sense of Data. Cambridge: Cambridge University Press, 400 p.

8. Shaikh, F. (2017). Deep Learning vs. Machine Learning - the essential differences you need to know. Available at: https://ru.esdifferent.com/differences-between-machine-learning-and-deeplearning (accessed 22.12.2019).

9. Eykhoff, P. (1974). Systems identification: parametrs and state estimation. Eindhoven, Netherlands: University of technology, $555 \mathrm{p}$.

10. Nikolenko, S., Kadurin, A. and Arhangelskaya, E. (2018). Glubokoye obucheniye. Pogruzheniye $v$ mir neyronnykh setey [Deep learning. Diving in the world of artificial neural networks]. St. Petersburg: Peter Publishing, 480 p.

11. Haykin, S. (2006). Neural Networks. A Comprehensive Foundation. Upper Saddle River, USA: Prentice hall, 2006. 1105 p.

12. Goreva, T.I., Portnyagin, N.N. and Pyukke, G.A. (2012). Neural network model diagnosis technical systems. Vestnik KRAUNC. Fiziko-matematicheskiye nauki, no. 1 (4), pp. 31-43. (in Russian)

13. Pyukke, G.A. and Strelnikov, D.S. (2013). Neural Network Approach to construct models of high-dimensional systems analysis. Bulletin of Kamchatka State Technical University, no. 24, pp. 21-28. (in Russian)

14. Kozlova, L.E. (2013). Research and development speed neural-network observer for control system of induction motor drives Modern problems of science and education, no. 5, pp. 44. (in Russian) 
15. Galizdra, V.I. and Babaev, Sh.B. (2011). Neural networks and data approximation. Nauchnyye i obrazovatelnyye problemy grazhdanskoy zashchity, no. 3, pp. 35-43. (in Russian)

16. Cybenko, G.V. (1989). Approximation by superpositions of a sigmoidal function. Mathematics of Control Signals and Systems, vol. 2, no. 4, pp. 303-314. DOI: https: 10.1007/BF02551274. (in Russian)

17. Gridin, V.N. and Solodovnikov, V.I. (2017). Osobennosti vnutrennego predstavleniya $i$ vizualizatsii izvlekayemoy iz dannykh informatsii s ispolzovaniyem modulnoy neyronnoy seti BP-SOM [Features of internal presentation and visualization of information extracted from data using the BP-SOM modular neural network]. Novyye informatsionnyye tekhnologii $\mathrm{v}$ avtomatizirovannykh sistemakh, no. 20, pp. 170-175. (in Russian)

18. Gorban, A.N. (1998). Obobshchennaya approksimatsionnaya teorema $i$ vychislitelnyye vozmozhnosti neyronnykh setey [Generalized approximation theorem and computational capabilities of artificial neural networks]. Siberian Gournal of Numerical Mathematics, vol. 1, no. 1, pp. 11-24. (in Russian)

19. Evdokimov, I.A. and Solodovnikov, V.I. (2015). Avtomatizatsiya postroyeniya neyronnoy seti $v$ ramkakh obektno-oriyentirovannogo podkhoda [The construction automation of the artificial neural network as a part of an object-oriented approach]. Novyye informatsionnyye tekhnologii $\mathrm{v}$ avtomatizirovannykh sistemakh, no. 18, pp. 89-97. (in Russian)

20. Kalistratov, T.A. (2014). Methods and algorithms of creation of structure of neuron network within universal approximation of functions. Tambov University Reports. Series: Natural and Technical Sciences, vol. 19, no. 6, pp. 1845-1848. (in Russian)

21. Bondarenko, I.B., Gatchin, Yu.A. and Geranichev, V.N. (2012). Synthesis of optimal artificial neural networks by modified genetic algorithm. Scientific and Technical Journal of Information Technologies, Mechanics and Optics, no. 2 (78), pp. 51-55. (in Russian)

22. Shumkov, E.A. and Chistik, I.K. (2013). Using genetic algorithms for training neural networks. Polythematic Online Scientific Journal of Kuban State Agrarian University, no. 91, pp. 455-464. (in Russian)

23. Diveev, A.I. (2015). Variatsionnyye metody simvolnoy regressii dlya zadach upravleniya $i$ identifikatsii [Variational methods of symbolic regression for control and identification problems]. System identification and control problems. Proceedings of the X International Conference, Moscow, SICPRO'15, pp. 141-148. (in Russian)

24. Diveev, A.I. (2016). Properties of superpositions of functions for numerical methods of symbolic regression. Cloud of Science, vol. 3, no. 2, pp. 290-301. (in Russian)

25. Dang, T.F., Diveev, A.I. and Sofronova, E.A. (2018). Mathematical models identification of objects and processes by symbolic regression. Cloud of Science, vol. 5, no. 1, pp. 147-162. (in Russian)

26. Diveev, A.I. and Lomakova, E.M. (2017). Method of binary analytic programming to look for optimal mathematical expression. RUDN Journal of Engineering Researches, vol. 18, no. 1, pp. 125-134. DOI: 10.22363/2312-8143-2017-18-1-125-134. (in Russian)

27. Ilin, I.V. (2018). Algoritmy izvlecheniya pravil iskusstvennykh neyronnykh setey [Algorithms of artificial neural network rule extraction]. Vestnik sovremennykh issledovaniy, no. 9.1 (24), pp. 149-152. (in Russian)

\section{INFORMATION ABOUT THE AUTHORS}

Igor E. Starostin, Candidate of Technical Sciences, Associate Professor, Electrical Engineering and Aviation Electrical Equipment Chair, Moscow State Technical University of Civil Aviation, starostinigo@yandex.ru 
Sergey P. Khalyutin, Doctor of Technical Sciences, Professor, Head of the Electrical Engineering and Aviation Electrical Equipment Chair, Moscow State Technical University of Civil Aviation,skhalutin@xlab-ns.ru

\title{
ИДЕНТИФИКАЦИЯ МОДЕЛЕЙ СИСТЕМ ИЗ ПОТЕНЦИАЛЬНО-ПОТОКОВЫХ УРАВНЕНИЙ НА ОСНОВЕ ГЛУБОКОГО ОБУЧЕНИЯ ПО ЭКСПЕРИМЕНТАЛЬНЫМ ДАННЫМ
}

\author{
И.Е. Старостин ${ }^{1}$, С.П. Халютин \\ ${ }^{1}$ Московский государственный технический университет гражданской авиации, \\ 2. Москва, Россия
}

Функционирование различных систем (в частности, технических объектов, живых клеток, атмосферы и океана и т.д.) определяется протеканием в них физических и физико-химических процессов. Для моделирования физико-химических процессов в общем случае ранее авторами был разработан потенциально-потоковый метод, основанный на экспериментальном исследовании (на результатах испытаний систем) свойств веществ и процессов. В общем случае из этих экспериментальных данных получается множество возможных значений этих свойств. Зная эти свойства веществ и процессов, начальное состояние системы, внешние воздействия на нее (или множество возможных значений этих величин), мы можем анализировать динамику физико-химических процессов в этой системе, а из нее - динамику имеющих практический смысл характеристик этой системы. Таким образом, из системы уравнений этого метода получается связь ненаблюдаемых характеристик этих систем с наблюдаемыми характеристиками рассматриваемых систем и лабораторных систем (в которой экспериментально исследуются свойства веществ и процессов в рассматриваемой системе). Т.к. потенциально-потоковые уравнения, описывающие физико-химические процессы, в общем случае достаточно сложные для аналитических преобразований, то вышеупомянутую связь необходимо получать численными методами. Настоящая работа посвящена использованию глубокого обучения как универсального аппроксиматора для получения описанной связи между характеристиками произвольных систем. Эти модели обучаются на динамиках характеристик рассматриваемых систем, полученных из потенциально-потоковых уравнений физикохимических процессов в них при разных значениях параметров, определяющих свойства веществ и процессов в этих системах, их начальных состояниях, внешних воздействиях.

Ключевые слова: физико-химические процессы, математическое моделирование, потенциально-потоковый метод, глубокое обучение.

\section{СПИСОК ЛИТЕРАТУРЫ}

1. Эткин В.А. Энергодинамика: синтез теорий переноса и преобразования энергии. СПб.: Наука, 2008. 409 с.

2. Jou D., Casas-Vázquez J., Lebon G. Extended irreversible thermodynamics. New York, USA: Springer, 2006. 528 p.

3. Старостин И.Е., Быков В.И. Кинетическая теорема современной неравновесной термодинамики. Raleigh, Noth Caroline, USA: Open Science Publishing, 2017. 229 c.

4. Старостин И.Е., Степанкин А.Г. Программная реализация методов современной неравновесной термодинамики. И система симуляции физико-химических процессов SimulationNonEqProcSS v.0.1.0. Lambert academic publishing RU, 2019. 132 c.

5. Starostin I.E., Khalyutin S.P. Obtaining robotic objects model from the equations of the potential-flow method $/ / 20^{\text {th }}$ international conference on micro/nanotechnologies and electron devices EDM, Novosibirsk, June 29 - July 3 2019. Pp. 678-684.

6. Старостин И.Е. Методика получения математической модели эксплуатируемого объекта из потенциально-потоковых уравнений физико-химических процессов // Научные горизонты. 2019. № 10 (26). С. 197-206. 
7. Flach P. Machine learning. The Art and Science of Algorithms that Make Sense of Data. Cambridge: Cambridge University Press, 2015. 400 p.

8. Shaikh F. Deep Learning vs. Machine Learning - the essential differences you need to know [Электронный pecypc]. Analytics Vidhya. URL: https://ru.esdifferent.com/differencesbetween-machine-learning-and-deep-learning (дата обращения 22.12.2019).

9. Eykhoff P. Systems identification: parametrs and state estimation. Eindhoven, Netherlands: University of technology, 1974. 555 p.

10. Николенко С., Кадурин А., Архангельская Е. Глубокое обучение. Погружение в мир нейронных сетей. СПб.: Питер, 2018. 480 с.

11. Haykin S. Neural Networks. A Comprehensive Foundation. Upper Saddle River, USA: Prentice hall, 2006. 1105 p.

12. Горева Т.И., Портнягин Н.Н., Пюкке Г.А. Нейросетевые модели диагностики технических систем // Вестник КРАУНЦ. Физ.-мат. науки. 2012. № 1 (4). С. 31-43.

13. Пюкке Г.А., Стрельников Д.С. Применение нейросетевого подхода при построении моделей анализа систем высокой размерности // Вестник Камчатского государственного технического университета. 2013. № 24. С. 21-28.

14. Козлова Л.Е. Разработка и исследование систем замкнутого асинхронного электропривода по схеме ТРН-АД с нейросетевым наблюдателем скорости // Современные проблемы науки и образования. 2013. № 5. С. 44.

15. Гализдра В.И., Бабаев Ш.Б. Нейронные сети и аппроксимация данных // Научные и образовательные проблемы гражданской защиты. 2011. № 3. С. 35-43.

16. Cybenko G.V. Approximation by superpositions of a sigmoidal function // Mathematics of Control Signals and Systems. 1989. Vol. 2, no. 4. Pp. 303-314. DOI: 10.1007/BF02551274

17. Гридин В.Н., Солодовников В.И. Особенности внутреннего представления и визуализации извлекаемой из данных информации с использованием модульной нейронной сети BP-SOM // Новые информационные технологии в автоматизированных системах. 2017. № 20. C. $170-175$.

18. Горбань А.Н. Обобщенная аппроксимационная теорема и вычислительные возможности нейронных сетей // Сибирский журнал вычислительной математики. 1998. Т. 1, № 1. C. 11-24.

19. Евдокимов И.А., Солодовников В.И. Автоматизация построения нейронной сети в рамках объектно-ориентированного подхода // Новые информационные технологии в автоматизированных системах. 2015. № 18. С. 89-97.

20. Калистратов T.A. Методы и алгоритмы создания структуры нейронной сети в контексте универсальной аппроксимации функций // Вестник Тамбовского университета. Серия Естественные и технические науки. 2014. Т. 19, № 6. С. 1845-1848.

21. Бондаренко И.Б., Гатчин Ю.А., Гераничев В.Н. Синтез оптимальных искусственных нейронных сетей с помощью модифицированного генетического алгоритма // Научно-технический вестник информационных технологий, механики и оптики. 2012. № 2 (78). C. $51-55$.

22. Шумков Е.А., Чистик И.К. Использование генетических алгоритмов для обучения нейронных сетей // Политематический Сетевой Электронный Научный журнал Кубанского государственного аграрного университета. 2013. № 91. С. 455-464.

23. Дивеев А.И. Вариационные методы символьной регрессии для задач управления и идентификации // Идентификация систем и задачи управления: труды X международной конференции, Москва, 26-29 января 2015 г. Институт проблем управления им. В.А. Трапезникова PAH, 2015. C. 141-148.

24. Дивеев А.И. Свойства суперпозиции функций для численных методов символьной регрессии // Cloud of Science. 2016. Т. 3, № 2. С. 290-301. 
25. Данг Т.Ф., Дивеев А.И., Софронова Е.А. Решение задач идентификации математических моделей объектов и процессов методом символьной регрессии // Cloud of Science. 2018. Т. 5, № 1. С. 147-162.

26. Дивеев А.И., Ломакова Е.М. Метод бинарного генетического программирования для поиска математического выражения // Вестник Российского университета дружбы народов: серия: инженерные исследования. 2017. Т. 18, № 1. С. 125-134. DOI: 10.22363/2312-8143-201718-1-125-134

27. Ильин И.В. Алгоритмы извлечения правил искусственных нейронных сетей // Вестник современных исследований. 2018. № 9.1 (24). С. 149-152.

\section{СВЕДЕНИЯ ОБ АВТОРАХ}

Старостин Игорь Евгеньевич, кандидат технических наук, доцент, доцент кафедры электротехники и авиационного электрооборудования МГТУ ГА, starostinigo@yandex.ru

Халютин Сергей Петрович, доктор технических наук, профессор, заведующий кафедрой электротехники и авиационного электрооборудования МГТУ ГА, skhalutin@xlab-ns.ru

Поступила в редакцию

Принята в печать
21.02 .2020

19.03.2020
Received

Accepted for publication
21.02.2020

19.03.2020 